\title{
SHORT COMMUNICATION \\ Anthropogenic materials used by birds to nest in an urban landscape of Costa Rica
}

\author{
Carolina Esquivel $^{1}(\mathbb{D})$, Jorge M. De la $\mathrm{O}^{2}(\mathbb{D})$, Steven Sánchez-Vargas ${ }^{2}(\mathbb{D})$, Sofía Paniagua ${ }^{2}$, Anthony \\ Esquivel-Cambronero ${ }^{2}$, Diego Núñez ${ }^{2}$, Gabriela Quesada-Ávila ${ }^{2}$
}

1. Universidad Nacional, Laboratorio de Biología Tropical, Apartado postal 86-3000, Heredia, Costa Rica; carolina.esquivel.dobles@una.ac.cr

2. Universidad Nacional, Apartado postal 86-3000, Heredia, Costa Rica; mdelao29@gmail.com, stevensagrav23@gmail.com, paniagua.sofia@gmail.com, aesquicam@gmail.com, godien88@gmail.com, gabrielaquesada20@gmail.com

\begin{abstract}
Introduction: Urbanization has affected the materials available for bird nesting, including anthropogenic materials that may be dangerous to the birds. Objective: To quantify the materials used by several bird species in an urbanized environment. Methods: We evaluated the composition of 20 nests in the campus of Universidad Nacional, Costa Rica. Results: $53 \%$ of nests contained anthropogenic waste, classified in 13 types; the most common were wool, strings and thread. The species with the highest percentage of anthropogenic nest weight was Campylorhynchus rufinucha. Conclusion: There is a widespread use of anthropogenic materials to nest in these urban Costa Rican birds.
\end{abstract}

Keywords: Nest, Plastic waste, Pollution, Wildlife-human interactions.
RESUMEN. "Materiales antropogénicos utilizados por aves para anidar en un paisaje urbano en Costa Rica". Introducción: La urbanización ha afectado los materiales disponibles para la anidación de aves, incluidos los materiales antropogénicos que pueden ser peligrosos para ellas. Objetivo: Cuantificar los materiales utilizados por varias especies de aves en un entorno urbanizado. Métodos: Evaluamos la composición de 20 nidos en el campus de la Universidad Nacional, Costa Rica. Resultados: $53 \%$ de los nidos contenían desechos antropogénicos, clasificados en 13 tipos; los más comunes fueron la lana, las cuerdas y el hilo. La especie con mayor porcentaje de peso antropogénico en sus nidos fue Campylorhynchus rufinucha. Conclusión: Existe un uso generalizado de materiales antropogénicos para anidar en estas aves urbanas costarricenses.

Palabras clave: Nido, Plástico, Contaminación, Interacciones humano-animal. 
Birds are recognized for their ability to build a wide variety of nest structures (Walsh, Hansell, Borello, \& Healy, 2011). The nest serves primarily as receptacle for eggs and fledglings, but can also provide other non-exclusive functions, such as providing signals to females for mate selection, protection against ectoparasites, a suitable microclimate for adults and offspring (Mainwaring, Hartley, Lambrechts, \& Deeming, 2014), and signaling aggressiveness to other conspecifics (Sergio et al., 2011). Given the significant role these processes play on bird's survival, nests are considered as an extended phenotype under strong natural and sexual selection, where design, construction and materials should be well adapted to local environmental conditions (Mainwaring et al., 2014).

Urbanization processes have modified the environment for plenty bird species, changing the type and abundance of available materials for nesting (Seress \& Liker, 2015). Discarded plastics and other anthropogenic materials are very abundant in urbanized and agricultural areas (Townsend \& Baker, 2014). These materials may constitute a threat for birds and other wildlife species (Hartwig, Clemens, \& Heckroth, 2007). A study on American crows, showed $85,2 \%$ of sampled nests contained anthropogenic materials and $5,6 \%$ of nestlings present in those nests were found entangled, dead, injured or malformed (Townsend \& Baker, 2014). In agricultural land, 4,6\% of Osprey nestlings were found entangled in baling twine used in their nests (Blem, Blem, \& Harmata, 2002). Northern garnets use synthetic rope preferentially over natural materials and a mean of 62 individuals die each year entangled in their nests (Votier, Archibald, Morgan, \& Morgan, 2011). Entanglement is not the only threat to birds using these materials. The incorporation of cigarette buds, have shown to have a positive effect at short term, as they serve as a parasite repellent (Suárez-Rodríguez, López-Rull, \& García, 2013), but birds show genotoxicity on the long term (Suárez-Rodríguez \& Macías-García, 2014). The effect of plastic pollution on terrestrial birds has received less attention than for marine birds (Sazima \& Angelo, 2016), and the use of anthropogenic waste in nests has mostly been anecdotally reported (reviewed in Townsend \& Baker 2014). Even though, most solid waste originates on land, nest affectation is particularly difficult to measure in terrestrial environments and entanglement of birds is difficult to spot (Townsend \& Baker 2014).

In order to contribute to the understanding of the use of plastics and other anthropogenic materials by several species of common inland birds for nest construction, we report a short evaluation of this so far disregarded environmental issue.

We conducted this study during August 2015 at Universidad Nacional campus, located in Heredia, Costa Rica. The campus has a mixture of buildings and gardens situated within an urbanized matrix. We did intensive searches collecting nests located from $0,5 \mathrm{~m}$ to $2 \mathrm{~m}$ above ground, as higher nests were inaccessible. During the sampling we checked if the nest was active, and we collected only empty or abandoned nests. Each nest was georeferenced with a Garmin GPS model GPSMAP ${ }^{\circledR}$ $64 \mathrm{~s}$.

The nests were identified by the late Óscar Ramírez-Alán, expert in ornithology, and some of the authors of this manuscript who were his students. All collected nests were simultaneously sun-dried for five hours, to eliminate humidity. The net dry weight for each nest was annotated, and nests were subsequently dismantled. Nest components were separated and classified as either organic components or anthropogenic materials. The latter were classified by type and the percentage of use was estimated as the total weight of anthropogenic waste out of the total dry weight of the nest. Graphical analysis was performed using Microsoft Excel.

We found 38 nests of which $18(47,4 \%)$ were left in the field because they did not appear to have any anthropogenic materials. We collected 20 nests of the following species: Turdus grayi Barteonap $1838(n=8)$, Campylorhynchus rufinucha Lesson $1838(n=5)$, Zonotrichia capensis Muller $1776(n=3)$, 
and four nests from unidentified species (Fig. 1). All these nests had at least one type of anthropogenic material (See Fig. 2 for examples).

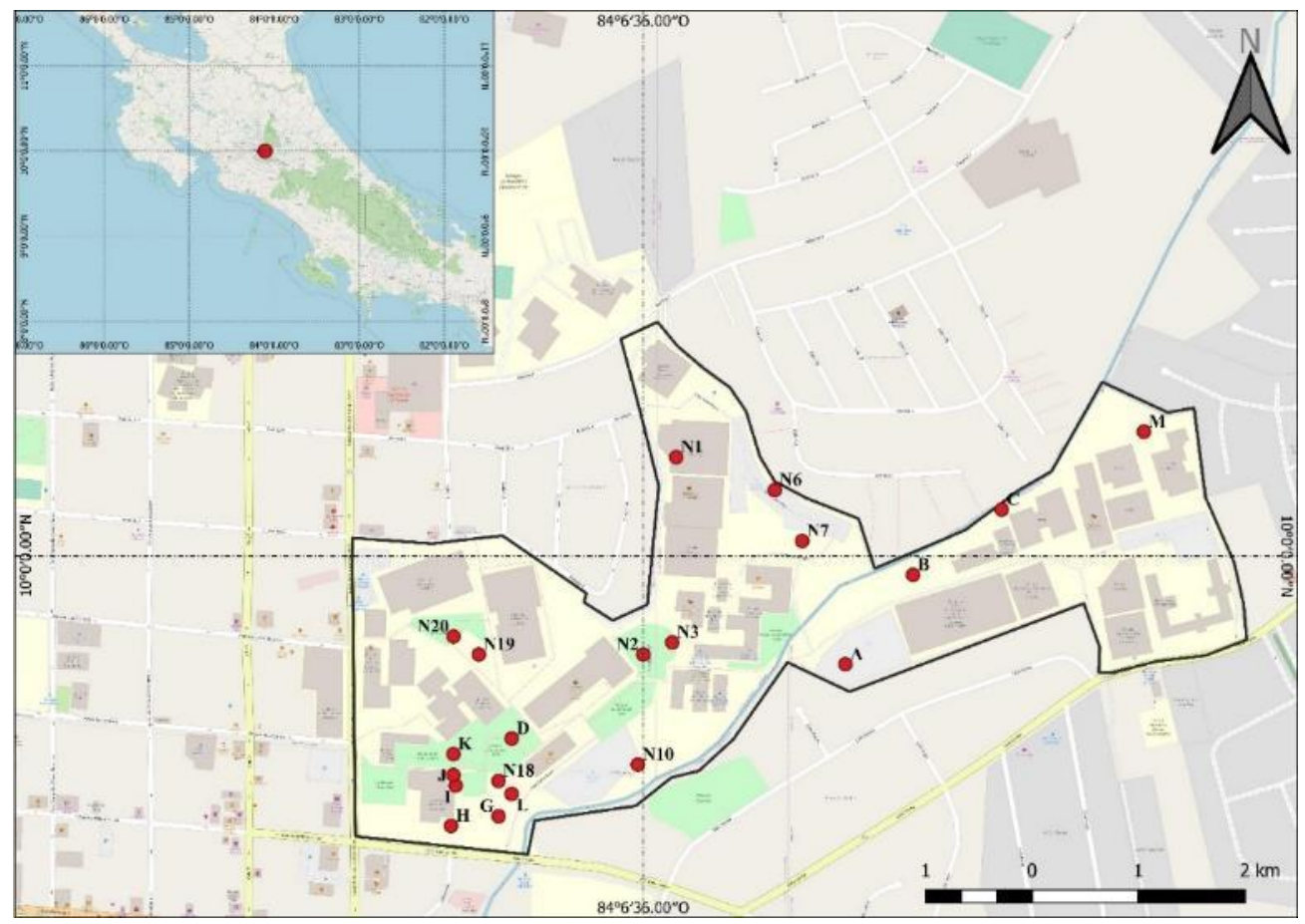

Fig. 1. Distribution of collected bird nests at Universidad Nacional, Heredia, Costa Rica. The campus is outlined with a black line, and each red dot represents a nest. Turdus grayi ( $n=8: \mathrm{N} 1, \mathrm{~N} 2, \mathrm{~N} 3, \mathrm{N10}, \mathrm{N} 18, \mathrm{H}, \mathrm{I}, \mathrm{J})$, Campylorhynchus rufinucha ( $n=5: A, B, C, D, G)$, Zonotrichia capensis ( $n=3: N 7, N 19, N 20)$, unidentified species $(n=4: N 6, K, L, M)$

The species with the highest percentage of nest weight comprised by anthropogenic material was Campylorhynchus rufinucha with a maximum of $19 \%$ of the total weight and an average percentage of 7,64\% (Table 1). We documented 13 different types of anthropogenic materials in nests, where wool, plastic string and thread showed the highest percentage of use (Fig. 3). We found one dead fledgling of $C$. rufinucha inside one of the collected nests.

\section{TABLE 1}

Sample size, mean percentage and range for the weight of anthropogenic waste found in nests of birds at Universidad Nacional, Heredia, Costa Rica

\begin{tabular}{llcc}
\hline \multicolumn{1}{c}{ Species } & $\mathbf{n}$ & $\begin{array}{c}\text { Mean percentage } \\
\mathbf{( \% )}\end{array}$ & $\begin{array}{c}\text { Range (min max) } \\
\mathbf{\%}\end{array}$ \\
\hline Campylorhynchus rufinucha & 5 & 7,64 & $2,3-19,1$ \\
Turdus grayi & 8 & 4,66 & $2,1-7,6$ \\
Zonotrichia capensis & 3 & 0,63 & $0,2-1,1$ \\
Unidentified species & 4 & 1,85 & $0,1-6,4$ \\
\hline
\end{tabular}




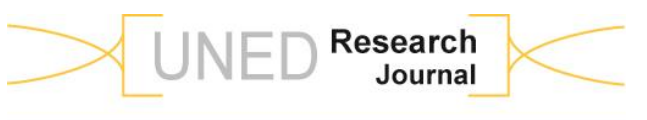

Cuadernos de Investigación UNED
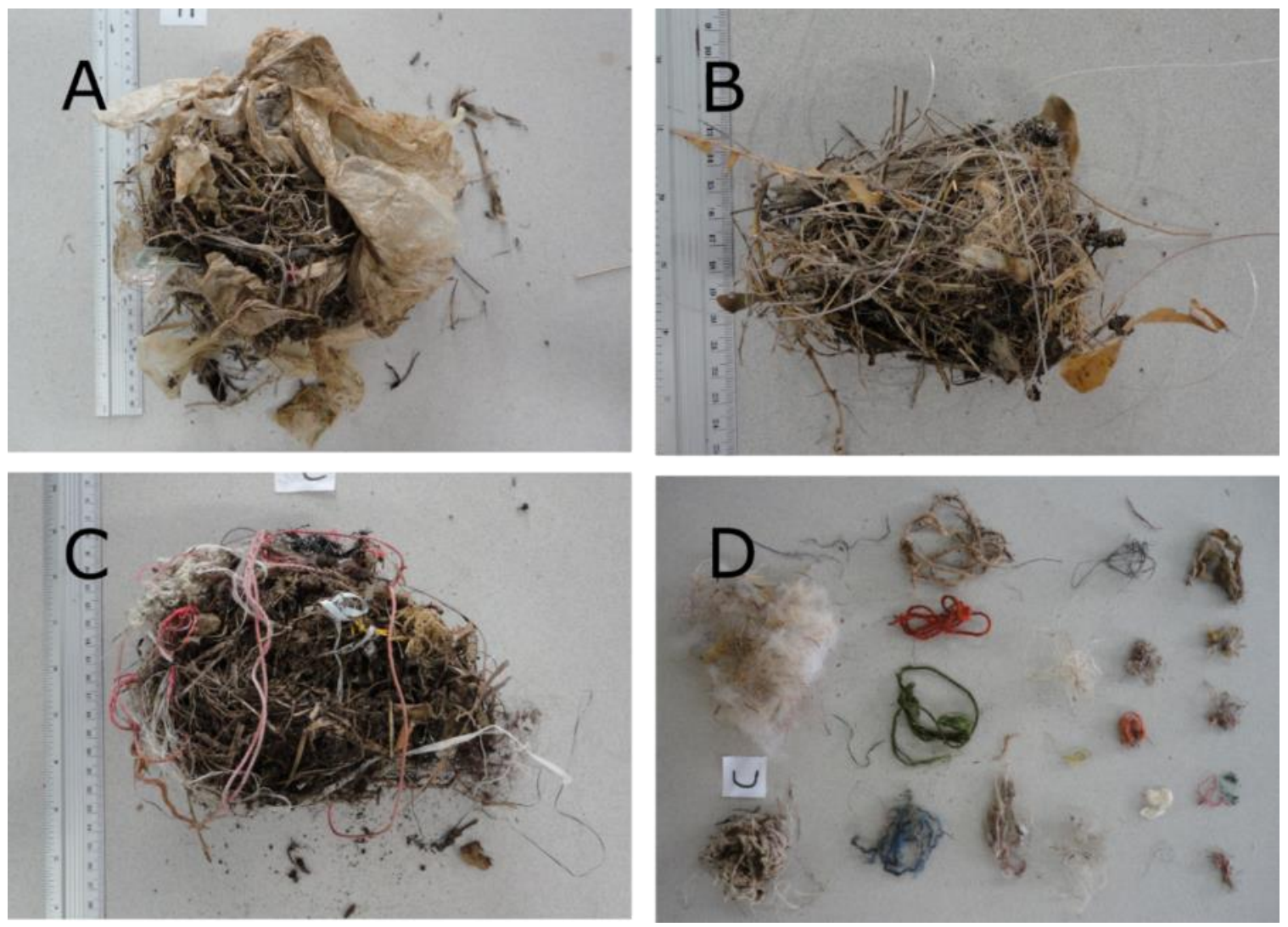

Fig. 2. Anthropogenic waste found in nests of birds at Universidad Nacional, Heredia, Costa Rica. A) Nest of Turdus grayi with plastic bags B) Nest of Zonotrichia capensis with a nylon fishing line C) Nest of Turdus grayi with different types of threads D) Anthropogenic waste found in a single nest of Campylorhynchus rufinucha, including polyester fibers, wool, and different types of threads.

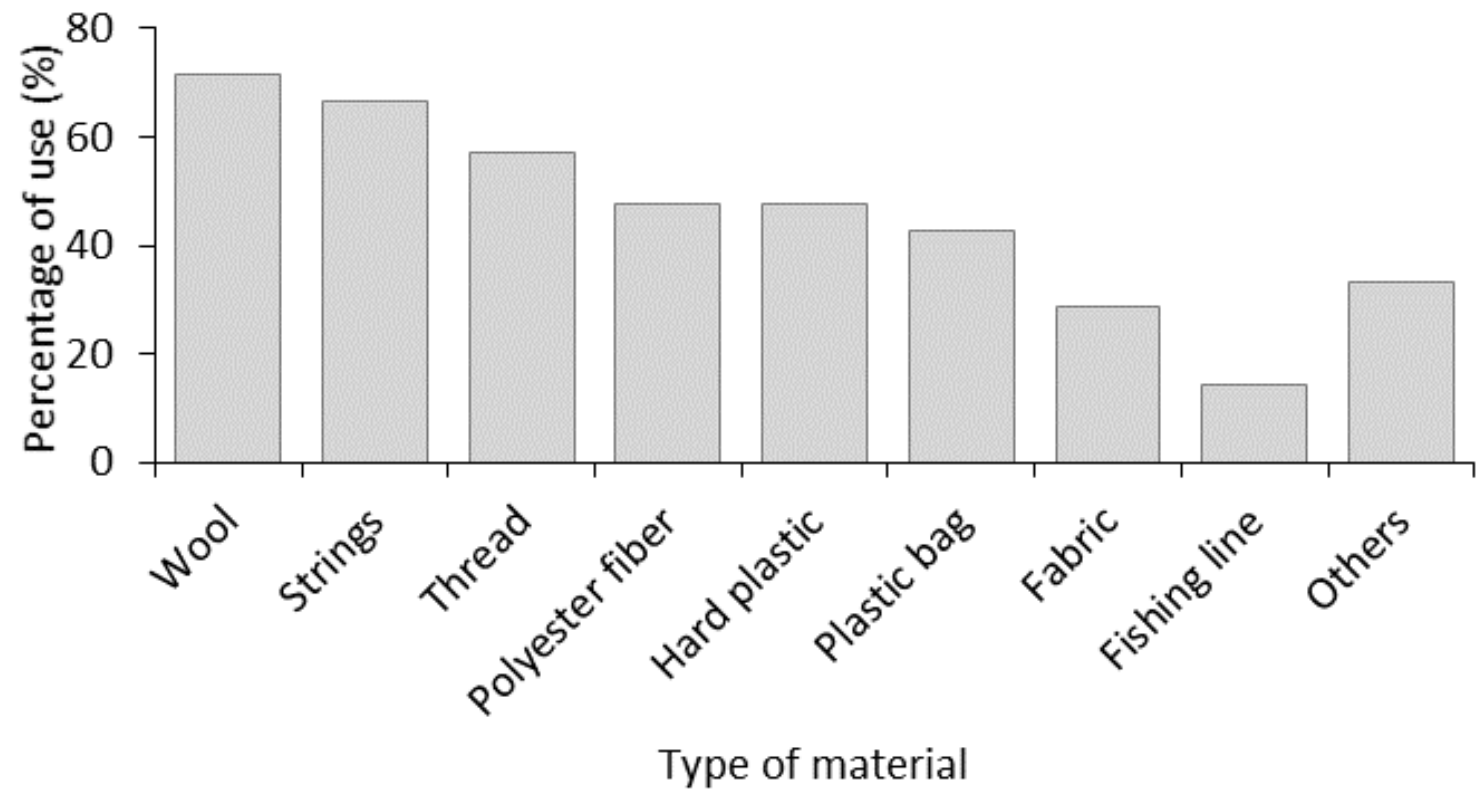

Fig. 3. Percentages of use for different types of anthropogenic waste from 20 bird nests in Heredia, Costa Rica. 
Our results demonstrate the widespread use of anthropogenic waste as nesting material as $52,6 \%$ of all nests found $(n=38)$ showed at least some level of implementation of waste as nesting material. Compared to other studies with inland birds, 85,3\% of American crows' nests contained anthropogenic waste (Townsend \& Baker, 2014). In addition, $89,29 \%$ of house sparrows' nests and $86,21 \%$ of house finches' nests have been reported to contain cellulose from cigarette buds (SuárezRodríguez \& Macías-García, 2014). In these studies, the authors reported negative effects for birds, especially for nestlings (Votier et al., 2011). In our study, we only report one dead Campylorhynchus rufinucha fledgling, but as we collected nests out of the reproductive period, it is possible that dead or injured fledglings were already predated or decomposed. In addition, 18 nests were left in the field; meaning the actual percentage of nests containing anthropogenic materials could be even greater. These nests can still have plastics in a very low percentage, or waste material that was not visible from the outside. Some authors have suggested that the incorporation of plastic debris in nests is correlated with de degree of human disturbance, for example urbanization, which increases the amount of solid wastes in the environment (Jagiello, López-García, Aguirre, \& Dylewski, 2020). For example, Jagiello Dylewski, Tobolka, and Aguirre (2019), reported that the incorporation of plastic debris in white storks' nests in Spain is associated with human activity. They found a correlation between plastic debris in nests and the closeness from landfills. The university campus has a solid waste management program, although it is located into an urban matrix, surrounded by neighborhoods and commercial areas. Also, the Pirro river runs across the campus (See Fig. 1). This river is known for being severely degraded and for carrying large amounts of solid waste and other pollutants (Vargas, Castro, Chacón, Monge, \& Obando, 2011).

Approximately half of the materials used by birds are fibers and strings of different types (Fig. 2). Birds may be using these materials because of their physical properties, as they can be sewn and serve as structural support (Bailey, Morgan, Bertin, Meddle, \& Healy, 2014). Polyester fibers were highly used by $C$. rufinucha, and all collected nests of this species showed these fibers used as lining.

We did not measure the effect of these materials on the reproductive success of birds. It has been proposed that birds which use anthropogenic debris as nesting materials may experience an increased nest predation because these materials can increment nest visibility (Borges \& Marini 2010). Moreover, they can cause increased mortality in adults and nestlings due to entanglement (Blem et al., 2002; Townsend \& Baker, 2014; Votier et al., 2011). On the other hand, the use of these materials has been seen as an opportunity for avifauna in their breeding season, and sometimes can successfully substitute the original ones if they are scarce (Cristofoli \& Sander, 2007; Cristofoli, dos Santos, Garcia, \& Sander, 2008; de Souza Petersen, Krüger, Dezevieski, Petry, \& Montone, 2016).

Waste removal from nests is impossible due to its large quantities and also this requires the removal of the nest (Voiter et al., 2011). Hence, reducing consumption of plastics, recycling (Lazarevic, Aoustin, Buclet, \& Brandt, 2010), waste recovery (Comăniță, Hlihor, Ghinea, \& Gavrilescu, 2016), implementation of bio-plastics environmentally degradable by microorganisms (Imam et al., 1999; Khoo, Tan, \& Chng, 2010) and other alternatives are recommended to reduce their potential damage to birds. Given that plastic production is increasing year after year, we can expect to find more effects of anthropogenic nest materials on bird populations with time. More studies are needed to understand which are the consequences for birds by using these materials in nests, and if the benefits of incorporating these materials surpass the risks to nestlings and adults. 


\section{ACKNOWLEDGEMENTS}

We want to thank F. Monge y V. Ramírez for their help during nest collection and separation of materials. A. Farah, K. Ulate, A. Hernández, S. Solano and S. Stephens provided insightful comments that helped improved previous versions of the manuscript. In memoriam of Prof. Óscar Ramírez-Alán (1976-2019).

\section{ETHICS, CONFLICT OF INTEREST, AND FUNDING STATEMENT}

The authors declare that they have fully complied with all pertinent ethical and legal requirements, both during the study and in the production of the manuscript; that there are no conflicts of interest of any kind; that all financial sources are fully and clearly stated in the acknowledgements section; and that they fully agree with the final edited version of the article. A signed document has been filed in the journal archives.

The statement of each author's contribution to the manuscript is as follows: C.E.: Original idea, data collection, analysis, writing, editing. J.M.D.O: Data collection, analysis, writing. S.S-V.: Data collection, analysis, writing. S.P.: Data collection, analysis, writing. A.E-C.: Data collection, analysis, writing. D.N.: Data collection, analysis, writing. G.Q-A.: Data collection, analysis, writing.

\section{REFERENCES}

Bailey, I. E., Morgan, K. V., Bertin, M., Meddle, S. L., \& Healy, S. D. (2014). Physical cognition: birds learn the structural efficacy of nest material. Proceedings of the Royal Society of London B: Biological Sciences, 281(1784), 2013322.

Blem, C.R., Blem, L.B., \& Harmata, P.J. (2002). Twine causes significant mortality in nestling ospreys. The Wilson Bulletin, 114(4), 528-529.

Borges, F.J.A., \& Marini, M.Â. (2010). Birds nesting survival in disturbed and protected Neotropical savannas. Biodiversity and Conservation, 19(1), 223-236.

Comăniță, E.D., Hlihor, R.M., Ghinea, C., \& Gavrilescu, M. (2016). Occurrence of plastic waste in the environment: ecological and health risks. Environmental Engineering \& Management Journal, 15(3), 675-685.

Cristofoli, S.I., \& Sander, M. (2007). Composição do ninho de corruíra: Troglodytes musculus Naumann, 1823 (Passeriformes: Troglodytidae). Biodiversidade Pampeana, 5(2), 6-8.

Cristofoli, S.I., dos Santos, C.R., Garcia, A.S., \& Sander, M. (2008). Composição do ninho de cambacica: Coereba flaveola Linnaeus, 1758 (Aves: Emberezidae). Biodiversidade Pampeana, 6(1), 30-33.

de Souza Petersen, E., Krüger, L., Dezevieski, A., Petry, M., \& Montone, R. (2016). Incidence of plastic debris in Sooty Tern nests: A preliminary study on Trindade Island, a remote area of Brazil. Marine pollution bulletin, 105(1), 373-376.

Hartwig, E., Clemens, T., \& Heckroth, M. (2007). Plastic debris as nesting material in a kittiwake (Rissa tridactyla) colony at the Jammerbugt, Northwest Denmark. Marine Pollution Bulletin, 54(5), 595 - 97.

Imam, S.H., Gordon, S.H., Shogren, R.L., Tosteson, T.R., Govind, N.S., \& Greene, R.V. (1999). Degradation of starch-poly ( $\beta$-hydroxybutyrate-co- $\beta$-hydroxyvalerate) bioplastic in tropical coastal waters. Applied and environmental microbiology, 65(2), 431-437.

Jagiello, Z., Dylewski, Ł., Tobolka, M., \& Aguirre, J. I. (2019). Life in a polluted world: A global review of anthropogenic materials in bird nests. Environmental Pollution, 251, 717-722. DOI: 10.1016/j.envpol.2019.05.028 
Jagiello, Z., López-García, A., Aguirre, J. I., \& Dylewski, Ł. (2020). Distance to landfill and human activities affects the debris incorporation into the white stork nests in urbanized landscape in central Spain. Environmental Science and Pollution Research, 27(24), 30893-30898.

Khoo, H.H., Tan, R.B., \& Chng, K.W. (2010). Environmental impacts of conventional plastic and bio-based carrier bags. The international journal of life cycle assessment, 15(3), 338-345.

Lazarevic, D., Aoustin, E., Buclet, N., \& Brandt, N. (2010). Plastic waste management in the context of a European recycling society: comparing results and uncertainties in a life cycle perspective. Resources, Conservation and Recycling, 55(2), 246-259.

Mainwaring, M.C., Hartley, I.R., Lambrechts, M.M., \& Deeming, D.C. (2014). The design and function of birds' nests. Ecology and Evolution, 4(20), 3909 - 3928. DOI: 10.1002/ece3.1054

Sazima, I., \& D’Angelo, G.B. (2016). Dangerous traps: Anhingas mistake anthropogenic debris for prey fish at an urban site in South-eastern Brazil. Revista Brasileira de Ornitologia, 23(4), 380-384.

Seress, G., \& Liker, A. (2015). Habitat urbanization and its effects on birds. Acta Zoologica Academiae Scientiarum Hungaricae, 61(4), 373-408.

Sergio, F., Blas, J., Blanco, G., Tanferna, A., López, L., Lemus, J.A., \& Hiraldo, F. (2011). Raptor nest decorations are a reliable threat against conspecifics. Science, 331(6015), 327 - 330. DOI: 10.1126/science.1199422

Suárez-Rodríguez, M., López-Rull, I., \& García, C.M. (2013). Incorporation of cigarette butts into nests reduces nest ectoparasite load in urban birds: new ingredients for an old recipe? Biology letters, 9(1), 20120931.

Suárez-Rodríguez, M., \& Macías García, C. (2014). There is no such a thing as a free cigarette; lining nests with discarded butts brings short-term benefits, but causes toxic damage. Journal of evolutionary biology, 27(12), 2719 - 2726. DOI: 10.1111/jeb.12531

Townsend, A.K., \& Baker, C.M. (2014). Plastic and the nest entanglement of urban and agricultural crows. PlosOne, 9(1), e88006. DOI: 10.1371/journal.pone.0088006

Vargas, M. R., Castro, L. P., Chacón, R. V., Monge, R. M., \& Obando, F. N. (2011). Evaluación ecológica rápida de un ecosistema urbano: el caso de la microcuenca del Río Pirro, Heredia, Costa Rica.Revista Geográfica de América Central, 2(47), 41-69.

Votier, S.C., Archibald, K., Morgan G., \& Morgan, L. (2011). The use of plastic debris as nesting material by a colonial seabird and associated entanglement mortality. Marine Pollution Bulletin, 62(1), $168-172$.

Walsh, P.T., Hansell, M., Borello, W.D., \& Healy, S.D. (2011). Individuality in nest building: Do Southern masked weaver (Ploceus velatus) males vary in their nest-building behaviour? Behavioural Processes, 88(1), 1-6. DOI: 10.1016/j.beproc.2011.06.011 